\title{
Adaptation and Psychometric Properties of the Brazilian Version of the Five-item Mental Health Index (MHI-5)
}

\author{
Adaptação e Propriedades Psicométricas da Versão Brasileira \\ do Índice de Saúde Mental (ISM-5)
}

\author{
Bruno Figueiredo Damásio*, ${ }^{*}$, Juliane Callegaro Borsa ${ }^{b}$ \& Silvia Helena Koller \\ ${ }^{a}$ Universidade Federal do Rio de Janeiro, Rio de Janeiro, Rio de Janeiro, Brasil, \\ ${ }^{b}$ Pontifícia Universidade Católica do Rio de Janeiro, Rio de Janeiro, Rio de Janeiro, Brasil \\ \& ' Universidade Federal do Rio Grande do Sul, Porto Alegre, Rio Grande do Sul, Brasil
}

\begin{abstract}
This study presents the psychometric properties of the Brazilian version of the five-item Mental Health Index (MHI-5). Participants were 524 subjects (69.8\% women), aged from 18 to 88 years old $(M=38.3$; $S D=13.26)$, from 17 Brazilian states. Exploratory and confirmatory factor analyses supported a single-factor solution. Reliability was assessed using alpha reliability, average variance extracted and composite reliability. Convergent validity was presented using the MHI-5, the Subjective Happiness Scale, the Satisfaction with Life Scale, and the General Health Questionnaire (GHQ-12). Discriminant validity, using the GHQ-12, showed that MHI-5 is a reliable measure to evaluate mental health. The scale presented strong evidence of validity and seems appropriate to evaluate mental health in the Brazilian population.

Keywords: Mental health index, validation, depression, anxiety, Brazil.
\end{abstract}

\begin{abstract}
Resumo
Este estudo apresenta as propriedades psicométricas da versão brasileira da escala de cinco itens Mental Health Index (MHI-5). Os participantes foram 524 sujeitos (69,8\% mulheres), com idades variando entre 18 e 88 anos $(M=38,3 ; D P=13,26)$, de 17 estados brasileiros. Análises fatoriais exploratórias e confirmatórias suportaram uma solução unidimensional. A fidedignidade foi avaliada utilizando confiabilidade alpha, variância média extraída, e confiabilidade composta. A validação convergente foi apresentada utilizando o MHI-5, a Escala de Felicidade Subjetiva, a Escala de Satisfação com a Vida, e o Questionário de Saúde Geral (QSG-12). A validade discriminante, utilizando o QSG-12 demonstrou que o MHI-5 é uma medida confiável para avaliar saúde mental. A escala apresentou evidências de validade consistentes, demonstrando ser uma medida apropriada para avaliação da saúde mental na população brasileira.

Palavras-chave: Índice de saúde mental, validação, depressão, ansiedade, Brasil.
\end{abstract}

Mental disorders constitute $13 \%$ of the total global burden of disease, surpassing both cardiovascular disease and cancer (Collins et al., 2011). Depression is the third leading contributor to the global disease burden, and it is expected that by 2030 it will be the illness with the highest disease burden in high-income countries (Mathers \& Loncar, 2006). Anxiety, in turn, appears to be the most frequent mental disorder in several countries, such as Australia, United States of America, Germany, The Netherlands (Baumeister \& Härter, 2007).

Specifically in Brazil, mental disorders is one of the main causes of disability pensions in the National Social Security Institute (INSS; Rombaldi, Silva, Gazalle, Aze-

* Mailing Address: Universidade Federal do Rio de Janeiro, Instituto de Psicologia, Departamento de Psicometria. Avenida Pasteur, 250, Fundos, Urca, Rio de Janeiro, RJ, Brasil, 22290-240 E-mail: brunofd.psi@gmail.com vedo, \& Hallal, 2010). According to the Brazilian Institute of Geography and Statistics (IBGE), depression affects 7.8 million Brazilians, which corresponds to $4.1 \%$ of the population (IBGE, 2008).

Depression, anxiety and other forms of mental disorders are related to huge losses of quality of life, both to the patient as well as to their relatives (Cuijpers, Smits, Donker, ten Have, \& de Graaf, 2009). Beyond the personal and relational impairment, the cost of depressive and anxiety disorders due to loss of productivity and use of health services allocates them as the top-five most costly diseases, including all disorders (Penninx et al., 2008; Smit et al., 2006).

Because of the incidence and negative consequences on personal and social development, a series of initiatives must be taken to prevent, diagnose and treat these problems. Based on the results of a global study conducted by the National Institute of Mental Health (NIMH), Collins 
et al. (2011) presented a series of priorities for improving the lives of people with mental illness around the world: (a) Identify root causes, risk and protective factors; (b) Advance prevention and implementation of early interventions; (c) Improve treatments and expand access to care; (d) Raise awareness of the global burden; (e) Build human resource capacity, and (f) Transform health-system and policy responses.

In order to treat, diagnose and to prevent mental health disorders the need of reliable psychometric instruments is evident. In the psychological and psychiatric literature, several instruments have been developed to assess the most common and prevalent mental health disorders (depression and anxiety, specifically). Examples of these instruments are: Brief Symptom Inventory (BSI; Derogatis \& Melisaratos, 1983), 12-item General Health Questionnaire (GHQ-12; Goldberg et al., 1997), Affect Balance Scale (ABS; Bradburn, 1969), Patient Health Questionnaire (PHQ, Spitzer, Kroenke, \& Williams, 1999), the Mental Health Continuum Short-Form (MHC-SF; Keyes, 2006). All these scales can be considered screening instruments. That is, measures that might assist professionals in accurately detect cases of both mental health and mental illness. In a systematic review of the literature, Mitchell and Coyne (2007) showed that by using depression screening instruments containing more than two items, professionals were able to accurately identify eight out of 10 cases of depressive patients. The results point out to the fact that screening instruments might be a useful tool in supporting clinical depression diagnosis.

Among the previously mentioned scales, the five-item Mental Health Index (MHI-5; McHorney \& Ware, $1995)$ is one of the most widely used scales to identify probable cases of both depressive and anxious patients. Composed by five items, the MHI-5 is a subscale of the SF-36 health-related quality of life measure (SF-36 HRQOL; Ware, Snow, Kosinski, \& Gandek, 1993). Several studies have provided evidence that the MHI-5 is a reliable instrument to assess depression and anxiety in clinical samples (e.g., Cuijpers et al., 2009; Ho et al., 2005; Kroenke et al., 2005; Navarro, Lara, \& Mondragón, 2002; Rumpf, Meyer, Hapke, \& John, 2001) as well as in the general population (e.g., Hoeymans, Garssen, Westert, \& Verhaak, 2004; Marques, Pais-Ribeiro, \& Lopez, 2011; Ostroff, Woolverton, Berry, \& Lesko, 1996; Yamazaki, Fukuhara, \& Green, 2005). For example, Rumpf et al. (2001) tested the performance of the MHI-5 in detecting psychiatric disorders, using the DSM-IV axis I as the gold standard. The authors found that the MHI-5 presented good performance for the screening of mood (area under the receiver operating characteristics curve, $\mathrm{AUC}=.88$ ) followed by anxiety disorders (AUC $=.71$ ). Other authors (e.g., Kelly, Dunstan, Lloyd, \& Fone, 2008) found that the MHI-5 present similar results when compared to the well-established mental health measure 12-item General Health Questionnaire (GHQ-12), suggesting that the MHI-
5 is a reliable measure to be used as a screening instrument to assess depressive and anxiety disorders.

An important issue of the MHI-5 is that it has presented adequate psychometric properties for different age groups from youngsters (Ostroff et al., 1996) to elderly (Friedman, Heisel, \& Delavan, 2005) and in different cultural contexts. Considering the importance of providing a brief instrument to assess symptoms of mood and anxiety disorders in the Brazilian clinical and non-clinical population, the present study aims to present the psychometric properties of the Brazilian MHI-5.

\section{Method}

\section{Participants}

Participants were 524 subjects (69.8\% women), aged from 18 to 88 years old $(M=38.3 ; S D=13.26)$, from 17 Brazilian states. A total of $37.6 \%$ was married, $25.4 \%$ single, $14.5 \%$ in cohabitation, $12.6 \%$ dating or engaged, $7.8 \%$ divorced, $.8 \%$ widow, and $1.3 \%$ in other situations (not specified). This sample is composed by participants who took part of a larger study entitled "Subjective wellbeing, orientations to happiness and its implications in psychological well-being and self-care related to health: Instrument Adapdation and Psychosocial Investigations", which aims to evaluate personal and contextual factors related to the positive psychological functioning.

\section{Instruments}

Sociodemographic Questionnaire. A sociodemographic questionnaire was used to gather data about gender, age, religiosity (presence or absence), educational level, financial income, job satisfaction and others.

5-item Mental Health Inventory (MHI-5). The MHI-5 (McHorney \& Ware, 1995) is one of the eight independent subscales that comprise the SF-36 (Ware et al., 1993). It is composed by five items and evaluates symptoms of depression (items b, d, and e) and anxiety (items a, and c) in both clinical and non-clinical population. The version used in this study (See Appendix) was achieved by using the Brazilian version of the SF-36 (Ciconelli, Ferraz, Santos, Meinão, \& Quaresma, 1999). However, it was used the five response categories of the SF-36 version 2 (all, most, some, a little, or none of the time). The scores were coded and ranged from 0 to 100 . Higher scores indicate better mental health.

Subjective Happiness Scale (SHS). The SHS is a 4-item test that evaluates happiness from the respondent's own perspective. The instrument has presented excellent psychometric properties in several countries (Moghnie \& Kazarian, 2012; Spagnoli, Caetano, \& Silva, 2010; Shimai, Otake, Utsuki, Ikemi, \& Lyubomirsky, 2004; Swami, 2008; Swami et al., 2009). In the validation study (Lyubomirsky \& Lepper, 1999), the authors found adequate reliability index, with alpha coefficients varying from .80 to .94 in 14 different samples $(N=2.732)$. The Brazilian version 
Damásio, B. F., Borsa, J. C. \& Koller, S. H. (2014). Validation and Psychometric Properties of the Brazilian Version of the Five-item Mental Health Index (MHI-5).

of the SHS was validated by Damásio, Zanon, and Koller (2014), and presented excellent fit indexes: CFI = 1.00; $\mathrm{TLI}=1.02 ;$ SRMR $=.006 ;$ RMSEA $(90 \% \mathrm{CI})=.000$ (.000 - .006). In this study, the goodness-of-fit indexes of the SHS were: $\mathrm{CFI}=1.00$; TLI $=1.00$; RMSEA $(90 \% \mathrm{CI})$ $=.01(.000-.072)$; SRMR $=.01$.

Satisfaction with Life Scale (SWLS). The Brazilian version of the SWLS was adapted and validated by Gouveia, Milfont, Fonseca, and Coelho (2009). The instrument is composed by five items which evaluate life-satisfaction from a subjective perspective (e.g., "In general, I am satisfied with my life”). In the validation study, the scale presented adequate psychometric properties (Reliability index, $\alpha=.80$; goodness-of-fit indexes $[\mathrm{GFI}]=.99 ; \mathrm{NNFI}=.98 ; \mathrm{CFI}=.99 ; \mathrm{RMSEA}$ $=.06 ;$ SRMR $=.02$ ). In this study, the goodness-of-fit indexes of the SWLS were: CFI $=1.00$; TLI $=1.00$; RMSEA $=.01(.00-.06) ;$ SRMR $=.01$.

12-item General Health Questionnaire (GHQ-12). The GHQ-12 (Goldberg et al., 1997) is the reduced version of the original General Health Questionnaire (Goldberg, 1972) and is one of the most widely used instruments to evaluate indicators of one's psychological well-being. Respondents rate the questionnaire on a scale ranging from 1 (more than habitual) to 4 (less than habitual). Brazilian validation studies reported a two-factor solution (depression and self-efficacy) as the most reliable, with Alpha reliability index ranging from .85 to .63 (Damásio, Machado, \& Silva, 2011; Gouveia, Barbosa, Andrade, \& Carneiro, 2010; Sarriera, Schwarcz, \& Câmara, 1996). In this study, the goodness-of-fit of this bifactorial solution (self-efficacy and depression) were: CFI = .98; TLI = .98; RMSEA $(90 \% \mathrm{CI})=.07(.060-.082) ; \mathrm{SRMR}=.05$.

\section{Data Collection}

Participants were assessed through different sources: Personal and media invitations, and snow-ball technique (Patton, 1990). Those who decided to participate answered a web-based survey. Free-consent term was added in the first page of the survey so that participants could only advance in the questionnaire by accepting the terms and giving their consent in participating on the study. This study was approved by the Federal University of Rio Grande do Sul Institutional Review Board (Ethics Committee).

\section{Data Analysis}

Initially, the total sample was randomly split in two halves. An exploratory factor analysis (EFA), using Principal Axis Factoring (PAF) extraction method, was performed with the first half of the sample $\left(n_{1}=262\right)$. The adequacy of the sample for this procedure was assessed using the Kaiser-Meyer-Olkin (KMO) and Bartlett's sphericity test.

A confirmatory factor analysis (CFA) was then conducted with the second half of the sample $\left(n_{2}=262\right)$ to cross-validate the obtained exploratory factor structure. The robust maximum likelihood extraction method (i.e., with corrections to data non-normality; Satorra \& Bentler,
2001), in a polychoric correlation matrix (Holgado-Tello, Chacón-Moscoso, Barbero-García, \& Vila-Abad, 2010) was used. The fit indices used included: the standardized root mean square residual (SRMR), the comparative fit index (CFI), and the Tucker-Lewis index (TLI). According to guidelines, model fit is acceptable if the following values are achieved: SRMR less than .08, CFI and TLI values greater than .90 (preferably greater than .95; Brown, 2006; Schreiber, Stage, Nora, \& Barlow, 2006).

Reliability was assessed using Alpha coefficient index (Cronbach, 1951), composite reliability (CR) and average variance extracted (AVE; Fornell \& Larcker, 1981). We expected Alpha coefficient and CR to be higher than .70, and AVE to be higher than .50 (Marôco, 2010).

Convergent validity (with all participants, $N=524$ ) was evaluated using the SHS, SWLS, and GHQ-12 scores. Positive and moderate correlations among MHI-5, SHS, SWLS, and self-efficacy factor of the GHQ-12, and negative and moderate correlations with "Depression” of the GHQ-12 are expected. Moderated correlations range from |.40| to |.69| (Cohen, Cohen, West, \& Aiken, 2002).

Discriminant validity (with all participants, $N=524$ ) was conducted using the GHQ-12 as the criteria measure. The obtained scores on the self-efficacy and depression factors of the GHQ-12 were split in two, according to the median (below the median, G1, low scores; above the median, G2, high scores). Student's $t$ test, using bootstrapping resampling method (10.000 resampling) with $99 \%$ C.I for mean difference $(\Delta M)$, was used in order to provide higher reliability to mean differences, to correct the non-normal distribution of the data and to control possible group-size bias (Haukoos \& Lewis, 2005). We expected that subjects with higher scores on self-efficacy (G2) present significant higher scores on the MHI-5 (better mental health), and that people with higher scores in depression (G2) will obtain significant lower scores in the MHI-5 (worse mental health). Furthermore, once the MHI-5 evaluates mental health by means of depression and anxiety symptoms, it is expected that effect-size measure (Cohen's $d$ ) of the $t$-tests would be higher for depression than for self-efficacy.

In order to evaluate the correlates among sociodemographic variables and the MHI-5, Pearson's correlations were conducted with age, educational level and financial income. Student's $t$ tests (using bootstrapping resampling method as mentioned above) were conducted for gender (male/female), job satisfaction (satisfied/unsatisfied), religiosity (presence/absence).

\section{Results}

\section{Exploratory Factor Analysis}

The EFA (KMO =.837; Bartlett's test of sphericity $\chi^{2}$ $[10]=574.365, p<.001$ ) presented a single-factor solution, which accounted for $64.58 \%$ of the explained variance of the construct. All five items loaded on the first factor with satisfactory (i.e., > .30) factor loadings (Table 1). 
Table 1

Exploratory Factor Analysis of the Brazilian Version of the 5-item Mental Health Index

\begin{tabular}{lc}
\hline & Factor \\
\cline { 2 - 2 } & Mental Health Index \\
\hline Item 4 & .79 \\
Item 2 & .77 \\
Item 3 & -.77 \\
Item 1 & .72 \\
Item 5 & -.68 \\
\hline Eigenvalue & 3.23 \\
Explained Variance & $64.58 \%$ \\
Mean (SD) & $67.97(7.00)$ \\
\hline
\end{tabular}

Note. SD - standard deviation.

Table 2

Pearson's Correlations among MHI-5, GHQ-12, SHS and SWLS

\begin{tabular}{lccccc}
\hline Constructs & 1 & 2 & 3 & 4 & 5 \\
\hline 1. Mental Health Index & - & & & & \\
2. Self-efficacy (GHQ-12) & $.55^{*}$ & - & & & \\
3. Depression (GHQ-12) & $-.61^{*}$ & $-.54^{*}$ & - & & \\
4. Subjective Happiness & $.63^{*}$ & $.42^{*}$ & $-.46^{*}$ & - & - \\
5. Satisfaction with life & $.59^{*}$ & $.39 *$ & $-.39^{*}$ & $.60^{*}$ & - \\
\hline
\end{tabular}

Note. MHI-5 - Five-item Mental Health Index; GHQ-12 - 12-item General Health Questionnaire; SHS - Subjective Happiness Scale; SWLS - Satisfaction with Life Scale.

$* p<.01$.

\section{Discriminant Validity}

Discriminant validity was assessed with GHQ-12, by dividing the participant's scores in high and low, according to the median for both subscales (self-efficacy and depression). As expected, mean differences, $t$-test value and
Confirmatory Factor Analysis

A CFA was performed with the second half of the sample $\left(n_{2}=162\right)$ to cross-validate the exploratory model. An excellent fit was achieved: SRMR $=.04$; CFI $=.97$; TLI $=.98$. Factor loadings ranged from -.67 (item 5) to .88 (item 2).

\section{Reliability Analysis}

Reliability analyses were assessed by three different criteria: Alpha's reliability, composite reliability (CR) and average variance extracted (AVE). Alpha reliability index was .86. Composite reliability (CR) and average variance extracted (AVE) were .82 and .59, respectively. These results strongly supported the adequacy and reliability of the single-factor solution of the Brazilian version of the MHI-5.

\section{Convergent Validity}

As expected, the MHI-5 correlated positively with self-efficacy, subjective happiness and life-satisfaction, and negatively with depression (Table 2). Furthermore, the moderated correlations suggest no overlapping among the measures.

Table 3

effect size (Cohen's $d$ ) on MHI-5 scores were higher for depression groups when compared to self-efficacy groups (Table 3). Whereas a medium-effect size (Cohen's $d>.3$ and $<.8$ ) for mean difference on the self-efficacy groups was obtained, a large effect was found on the depression groups (Cohen's $d>.8$ ).

Student's t Tests, Mean Differences and Effect-Sizes of the MHI-5, using GHQ-12 as Criterion Variable

\begin{tabular}{|c|c|c|c|c|c|c|}
\hline & & \multicolumn{2}{|c|}{ MHI-5 } & \multirow{2}{*}{$t$-value } & \multirow{2}{*}{$p$-value } & \multirow{2}{*}{ Cohen's $d$} \\
\hline & & Mean $(S D)$ & $\Delta M[99 \% \mathrm{CI}]$ & & & \\
\hline \multirow{2}{*}{$\begin{array}{l}\text { Self-Efficacy } \\
\text { (GHQ-12) }\end{array}$} & G1 & $71.73(15.90)$ & \multirow{2}{*}{$10.12[6.87-13.24]$} & \multirow{2}{*}{7.46} & \multirow{2}{*}{.001} & \multirow{2}{*}{.72} \\
\hline & G2 & 81.85 (11.99) & & & & \\
\hline \multirow{2}{*}{$\begin{array}{l}\text { Depression } \\
\text { (GHQ-12) }\end{array}$} & G1 & 82.24 (11.23) & \multirow{2}{*}{14.34 [11.22-17.52] } & \multirow{2}{*}{-14.34} & \multirow{2}{*}{.001} & \multirow{2}{*}{1.04} \\
\hline & G2 & $67.90(15.83)$ & & & & \\
\hline
\end{tabular}

Note. MHI-5 - Five-item Mental Health Index; GHQ-12 - 12-item General Health Questionnaire; SD - standard deviation; $\Delta M$ mean difference; $\mathrm{CI}$ - confidence interval. 
Damásio, B. F., Borsa, J. C. \& Koller, S. H. (2014). Validation and Psychometric Properties of the Brazilian Version of the Five-item Mental Health Index (MHI-5).

Mental Health Index and Sociodemographic Variables

The levels of mental health correlated positively with age $(r=.29, p<.0001)$, financial income $(r=.25, p<.0001)$ and educational level $(r=.19, p<.0001)$. Student's $t$ test presented no significant results for gender $(M$ $S D=15.91 ; M=74.69, S D=15.34, t[522]$ $=-1.052, p=.29)$ and religiosity ( $M$ female $=75.83, S D$ presence $=14.89 ; M_{\text {absence }}=74.29, S D_{\text {absence }}^{\text {presence }}=16.29, t[522]=$ $-1.052, p=.29)$. However, significant effects were found for job satisfaction $\left(M_{\text {satisfied }}=77.11, S D_{\text {satisfied }}=14.43 ; M\right.$ unsatisfied $=63.32, S D_{\text {unsatisfied }}=16.12, \Delta M=13.78$ [99\% I.C $=8.26-19.33], E . P=2.14 ; t[453]=7.00, p<.0001)$.

\section{Discussion}

The Brazilian version of the MHI-5 presents excellent psychometric properties. Exploratory and confirmatory factor analyses supported a single-factor solution, with all 5 items loading on the expected factor. A good percentage of explained variance was achieved in the EFA, suggesting low levels of residuals (Peterson, 2000). This result was supported in the CFA, in which adequate fit indexes were obtained, including low level of residuals $($ SRMR $=.04)$.

Alpha's reliability supported the adequate inter-item correlation of the items. AVE supported once more that the extracted variance was high, and residuals of the MHI-5 were low. Lastly, CR supported the assumption that the items of the MHI-5 are all reflective of the mental health construct.

Convergent validity also provided evidences of construct validity to MHI-5. According to the results, people with higher mental health tend to be happier, more satisfied with life and to present higher levels of self-efficacy. On the other hand, people with higher levels of mental health also present low levels of depression. These results corroborate a large body of research suggesting that mental health impacts cognitive judgments (satisfaction with life and self-efficacy; Marques et al., 2011), as well as emotional perceptions about one's life (happiness; Bray \& Gunnell, 2006; Salguero, Palomera, \& Férnandez-Berrocal, 2012). It is important to note that, according to the MHI-5, mental health is measured as the absence of symptoms of depression and anxiety. Thus, these correlations corroborate the idea that subjective assessment of one's life (subjective happiness and life satisfaction) is partially dependent on the absence of mental illness (Keyes, 2005).

Finally, discriminant validity was tested by using the GHQ-12 as the criteria measure. Subjects' scores in the self-efficacy and depression subscales were divided in low and high levels according to the median. As expected, selfefficacy and depression presented positive and moderate correlations with the MHI-5. More than that, the effectsize of the t-test was higher for the depression than for the self-efficacy subscale. Once the MHI-5 is a measure that evaluates symptoms of depression and anxiety (Cuijpers et al., 2009; Rumpf et al., 2001; Ware \& Gandek, 1998), this result was expected.
The mental health index increased with age. When mental health is viewed as the absence of symptoms of psychopathology, just as in this case, studies suggest that mental health is better in later phases of the adult lifespan (Kessler, Mickelson, Walters, Zhao, \& Hamilton, 2004; Westerhof \& Keyes, 2010). Mental health index also correlated positively with financial income and educational level. Regarding financial income, several explanations are possible: People with lower profitability have less access to health services (such as psychotherapy, hospitals, etc.) and are more exposed to at-risk situations (Ludermir, 2008). Moreover, people with lower profitability have more difficult to meet their basic and personal needs. Explanations to the positive relation between mental health index and educational level are similar, once financial income and educational level are positively related (in this study, $r=.56, p<.0001)$. More than that, empirical evidence has suggested that people with higher educational level presents more self-care related to health, thus decreasing mental and physical illness (Akyol, Çetinkaya, Bakan, Yarali, \& Akkus, 2007; Sousa et al., 2010).

No differences were found between gender and religiosity (presence or absence). However, job satisfaction presented significant effects on the levels of mental health. This last result corroborates the literature, which presents significant relations among job satisfaction and mental health (Faragher, Cass, \& Cooper, 2005). It is well-known that job dissatisfaction is predictive of occupational illness (Faragher et al., 2005). In this perspective, it is possible that people unsatisfied with their job presents higher levels of occupational distress, which reflects in other areas of the subject's life. Another possible explanation relates to the meaning of the job in one's life. Several authors have extensively demonstrated that the job is one of the most important sources of meaning in the adulthood (Schnell, 2009). Thus, people unsatisfied with their jobs are unsatisfied with an important issue of their lives, which reflects in their mental health index.

This study presents several limitations. Participants were assessed by convenience, providing a non-representative sample of the Brazilian population. From the total respondents, most were women. Finally, this study did not include clinical samples. More studies are necessary to provide further validity evidence to the MHI-5.

\section{Final Considerations}

The MHI-5 is a reliable measure of mental health index and it has been worldwide used as a brief screening questionnaire for detecting psychopathological disorders including mood and anxiety disorders. The Brazilian version of the MHI-5 presented excellent psychometric properties and seems to be a reliable measure to evaluate levels of mental health on the Brazilian population. Considering the importance of the mental health index as a fundamental component of well-being of the general population, researchers and clinical practitioners might benefit of the scale once they will be able to evaluate 
mental health and to screen possible cases of depressive and anxious patients by a short and reliable instrument.

\section{References}

Akyol, A. D., Çetinkaya, Y., Bakan, G., Yarali, S., \& Akkus, S. (2007). Self-care agency and factors related to this agency among patients with hypertension. Journal of Clinical Nursing, 16(4), 679-687. doi:10.1111/j.1365-2702.2006.01656.x

Baumeister, H., \& Härter, M. (2007). Prevalence of mental disorders based on general population surveys. Social Psychiatry and Psychiatric Epidemiology, 42(7), 537-546. doi:10.1007/ s00127-007-0204-1

Bradburn, N. M. (1969). The structure of psychological wellbeing. Chicago, IL: Aldine.

Bray, I., \& Gunnell, D. (2006). Suicide rates, life satisfaction and happiness as markers for population mental health. Social Psychiatry and Psychiatric Epidemiology, 41(5), 333-337. doi:10.1007/s00127-006-0049-z

Brazilian Institute of Geography and Statistics. (2008). Síntese de Indicadores Sociais. Rio de Janeiro, RJ: Author. Retrieved September 19, 2012, from http://www.ibge.gov.br/ sinteseindicsociais2008

Brown, T. A. (2006). Confirmatory factor analysis for applied research. New York: The Guilford Press.

Ciconelli, R. M., Ferraz, M. B., Santos, W., Meinão, I., \& Quaresma, M. R. (1999). Tradução para a língua portuguesa e validação do Questionário Genérico de Avaliação de Qualidade de Vida SF-36 (Brasil SF-36). Revista Brasileira de Reumatologia, 39(3), 143-150.

Cohen, J., Cohen P., West, S. G., \& Aiken, L. S. (2002). Applied multiple regression / Correlation analysis for the behavioral sciences ( $3^{\text {rd }}$ ed.). New York: Psychology Press.

Collins, P. Y., Patel, V., Joestl, S. S., March, D., Insel, T. R., Daar, A. S., ...Stein, D. J. (2011). Grand challenges in global mental health. Nature, 475(7354), 27-30. doi:10.1038/475027a

Cronbach, L. J. (1951). Coefficient alpha and the internal structure of tests. Psychometrika, 16, 297-334.

Cuijpers, P., Smits, N., Donker, T., ten Have, M., \& de Graaf, R. (2009). Screening for mood and anxiety disorders with the five-item, the three-item, and the two-item Mental Health Inventory. Psychiatry Research, 168(3), 250-255. doi:10.1016/j. psychres.2008.05.012

Damásio, B. F., Machado, W. L., \& Silva, J. P. (2011). Estrutura fatorial do Questionário de Saúde Geral (QSG-12) em uma amostra de professores escolares. Avaliação Psicológica, 10(1), 99-105.

Damásio, B. F., Zanon, C., \& Koller, S. H. (2014). Validation and psychometric properties of the Brazilian version of the Subjective Happiness Scale. Universitas Psychologica, 13(1), 1-13. doi:10.11144/Javeriana.UPSY13-1.vppb

Derogatis, L. R., \& Melisaratos, N. (1983). The Brief Symptom Inventory: An introductory report. Psychological Medicine, 13(1), 595-605. doi:10.1017/S0033291700048017

Faragher, E. B., Cass, M., \& Cooper, C. L. (2005). The relationship between job satisfaction and health: A meta-analysis. Occupational and Environmental Medicine, 62(2), 105-112. doi:10.1136/oem.2002.006734

Fornell, C., \& Larcker, D. F. (1981). Evaluating structural equations models with unobservable variables and measurement error. Journal of Marketing, 18(1), 39-50. doi: 10.2307/3151312

Friedman, B., Heisel, M., \& Delavan, R. (2005). Validity of the SF-36 five-item Mental Health Index for major depression in functionally impaired, community-dwelling elderly patients.
Journal of the American Geriatrics Society, 53(11), 19781985. doi:10.1111/j.1532-5415.2005.00469.x

Goldberg, D. P. (1972). The detection of psychiatric illness by questionnaire. London: Oxford University Press.

Goldberg, D. P., Gater, R., Sartorius, N., Ustun, T. B., Piccinelli, M., Gureje, O., \& Rutter, C. (1997). The validity of two versions of the GHQ in the WHO study of mental illness in general health care. Psychological Medicine, 27(1), 191-197.

Gouveia, V. V., Barbosa, G. A., Andrade, E. O., \& Carneiro, M. B. (2010). Factorial validity and reliability of the General Health Questionnaire (GHQ-12) in the Brazilian physician population. Cadernos de Saúde Pública, 26(7), 1439-1445. doi:10.1590/S0102-311X2010000700023

Gouveia, V. V., Milfont, T., Fonseca, P. N., \& Coelho, J. A., P. M. (2009). Life satisfaction in Brazil: Testing the psychometric properties of the Satisfaction with Life Scale (SWLS) in five Brazilian samples. Social Indicators Research, 90(2), 267-277. doi:10.1007/s11205-008-9257-0

Haukoos, J. S., \& Lewis, R. J. (2005). Advanced statistics: Bootstrapping confidence intervals for statistics with "difficult” distributions. Academic Emergency Medicine, 12(4), 360-365. doi:10.1197/j.aem.2004.11.018

Ho, P. M., Masoudi, F. A., Spertus, J. A., Peterson, P. N., Shroyer, A. L., McCarthy, M., ...Rumsfeld, J. S. (2005). Depression predicts mortality following cardiac valve surgery. The Annals of Thoracic Surgery, 79(4), 1255-1259. doi:10.1016/j. athoracsur.2004.09.047

Hoeymans, N., Garssen, A. A., Westert, G. P., \& Verhaak, P. F. M. (2004). Measuring mental health of the Dutch population: A comparison of the GHQ-12 and the MHI-5. Health and Quality of Life Outcomes, 2(23), 23-29.

Holgado-Tello, F., Chacón-Moscoso, S., Barbero-García, I., \& Vila-Abad, E. (2010). Polychoric versus Pearson correlations in exploratory and confirmatory factor analysis of ordinal variables. Quality and Quantity, 44(1), 153-166. doi:10.1007/ s11135-008-9190-y

Kelly, M. J., Dunstan, F. D., Lloyd, K., \& Fone, D. L. (2008). Evaluating cutpoints for the MHI-5 and MCS using the GHQ12: A comparison of five different methods. BMC Psychiatry, 8(1), 10. doi:10.1186/1471-244X-8-10

Kessler, R. C., Mickelson, K. D., Walters, E. E., Zhao, S., \& Hamilton, L. (2004). Age and depression in the MIDUS Survey. In O. G. Brim, C. D. Ryff, \& R. C. Kessler (Eds.), How healthy are we: A national study of well-being at midlife (pp. 227-251). Chicago, IL: University of Chicago Press.

Keyes, C. L. M. (2005). Mental illness and/or mental health? Investigating axioms of the complete state model of health. Journal of Consulting and Clinical Psychology, 73(3), 539548. doi:10.1037/0022-006X.73.3.539

Keyes, C. L. M. (2006). The subjective well-being of America's youth: Toward a comprehensive assessment. Adolescent and Family Health, 4(1), 3-11.

Kroenke, C. H., Bennett, G. G., Fuchs, C., Giovannucci, E., Kawachi, I., Schernhammer, E., ...Kubzansky, L. D. (2005). Depressive symptoms and prospective incidence of colorectal cancer in women. American Journal of Epidemiology, 162(9), 839-848. doi:10.1093/aje/kwi302

Ludermir, A. B. (2008). Desigualdades de classe e gênero e saúde mental nas cidades. Physis: Revista de Saúde Coletiva, 18(3), 451-467. doi:10.1590/S0103-73312008000300005

Lyubomirsky, S., \& Lepper, H. S. (1999). A measure of subjective happiness: Preliminary reliability and construct validation. Social Indicators Research, 46(1), 137-155. doi:10.1023/A:1006824100041 
Damásio, B. F., Borsa, J. C. \& Koller, S. H. (2014). Validation and Psychometric Properties of the Brazilian Version of the Five-item Mental Health Index (MHI-5).

Marôco, J. (2010). Análise de equações estruturais: Fundamentos teóricos, software e aplicações. Pero Pinheiro, Portugal: Report Number.

Marques, S. C., Pais-Ribeiro, J. L., \& Lopez, S. J. (2011). Use of the "Mental Health Inventory - 5" with Portuguese 10-15 years old. The Spanish Journal of Psychology, 14(1), 478-485. doi:10.5209/rev_SJOP.2011.v14.n1.43

Mathers, C. D., \& Loncar, D. (2006). Projections of global mortality and burden of disease from 2002 to 2030. PLoS Medicine, 3(11), e442. doi:10.1371/journal.pmed.0030442.

McHorney, C. A., \& Ware, J. E., Jr. (1995). Construction and validation of an alternate form general mental health scale for the Medical Outcomes Study Short-Form 36-Item Health Survey. Medical Care, 33(1), 15-28.

Mitchell, A. J., \& Coyne, J. C. (2007). Do ultra-short screening instruments accurately detect depression in primary care? British Journal of General Practice, 57(535), 144-151.

Moghnie, L., \& Kazarian, S. S. (2012). Subjective happiness of Lebanese college youth in Lebanon: Factorial structure and invariance of the Arabic Subjective Happiness Scale. Social Indicators Research, 109(2), 203-210. doi:10.1007/ s11205-011-9895-5

Navarro, C., Lara, M. A., \& Mondragón, L. (2002). Validez y confiabilidad del MHI-5 para evaluar la depresión de mujeres en primer nivel de atención. Salud Mental, 25(6), 13-20.

Ostroff, J. S., Woolverton, K. S., Berry, C., \& Lesko, L. M. (1996). Use of the Mental Health Inventory with adolescents: A secondary analysis of the Rand Health Insurance study. Psychological Assessment, 8(1), 105-107. doi:10.1037/10403590.8.1.105

Patton, M. Q. (1990). Qualitative evaluation and research methods $\left(2^{\text {nd }}\right.$ ed.). Newbury Park, CA: Sage.

Penninx, B. W. J. H., Beekman, A. T. F., Smit, J. H., Zitman, F. G., Nolen, W. A., Spinhoven, P., ...Dyck, R. V. (2008). The Netherlands Study of Depression and Anxiety (NESDA): Rationale, objectives and methods. International Journal of Methods in Psychiatric Research, 17(3), 121-140. doi:10.1002/mpr.256

Peterson, R. A. (2000). A meta-analysis of variance accounted for and factor loadings in exploratory factor analysis. Marketing Letters, 11(3), 261-275.

Rombaldi, A. J., Silva, M. C. da, Gazalle, F. K., Azevedo, M. R., \& Hallal, P. C. (2010). Prevalence of depressive symptoms and associated factors among southern Brazilian adults: Cross-sectional population-based study. Revista Brasileira de Epidemiologia, 13(4), 620-629. doi:10.1590/S1415-790X2010000400007

Rumpf, H. J., Meyer, C., Hapke, U., \& John, U. (2001). Screening for mental health: Validity of the MHI-5 using DSM-IV Axis I psychiatric disorders as gold standard. Psychiatry research, 105(3), 243-253. doi:10.1016/S0165-1781(01)00329-8.

Salguero, J., Palomera, R., \& Fernández-Berrocal, P. (2012). Perceived emotional intelligence as predictor of psychological adjustment in adolescents: A 1-year prospective study. European Journal of Psychology of Education, 27(1), 21-34. doi:10.1007/s10212-011-0063-8

Sarriera, J. C., Schwarcz, C., \& Câmara, S. G. (1996). Bem-estar psicológico: Análise fatorial da escala de Goldberg (GHQ12) numa amostra de jovens. Psicologia: Reflexão e Crítica, 9(1), 293-306.

Satorra, A., \& Bentler, P. M. (2001). A scaled difference chi-square test statistic for moment structure analysis .Psychometrika, 66(4), 507-514. doi:10.1007/BF02296192
Schnell, T. (2009). The Sources of Meaning and Meaning in Life Questionnaire (SoMe): Relations to demographics and well-being. Journal of Positive Psychology, 4(6), 483-499. doi:10.1080/17439760903271074

Schreiber, J. B., Stage, F. K., King, J., Nora, A., \& Barlow, E. A. (2006). Reporting structural equation modeling and confirmatory factor analysis results: A review. Journal of Educational Research, 99(6), 324-337.

Shimai, S., Otake, K., Utsuki, N., Ikemi, A., \& Lyubomirsky, S. (2004). Development of a Japanese version of the Subjective Happiness Scale (SHS), and examination of its validity and reliability. Nihon Koshu Eisei Zasshi, 51(10), 845-853.

Smit, F., Cuijpers, P., Oostenbrink, J., Batelaan, N., de Graaf, R., \& Beekman, A. (2006). Costs of nine common mental disorders: Implications for curative and preventive psychiatry. Journal of Mental Health Policy and Economics, 9(4), 193-200.

Sousa, V. D., Zauszniewski, J. A., Bergquist-Beringer, S., Musil, C. M., Neese, J. B., \& Jaber, A. F. (2010). Reliability, validity and factor structure of the Appraisal of Self-Care Agency Scale - Revised (ASAS-R). Journal of Evaluation in Clinical Practice, 16(6), 1031-1040. doi:10.1111/j.13652753.2009.01242.x

Spagnoli, P., Caetano, A., \& Silva, A. (2010). Psychometric properties of a Portuguese version of the Subjective Happiness Scale. Social Indicators Research, 105(1), 137-143. doi:10.1007/s11205-010-9769-2

Spitzer, R. L., Kroenke, K., \& Williams, J. B. (1999). Validation and utility of a self-report version of PRIME-MD: The PHQ primary care study. Primary Care Evaluation of Mental Disorders. Patient Health Questionnaire. JAMA, 282(18), 1737-1744.

Swami, V. (2008). Translation and validation of the Malay Subjective Happiness Scale. Social Indicators Research, 88(2), 347-353. doi:10.1007/s11205-007-9195-2

Swami, V., Stieger, S., Voracek, M., Dressler, S. G., Eisma, L., \& Furnham, A. (2009). Psychometric evaluation of the Tagalog and German Subjective Happiness Scales and a cross-cultural comparison. Social Indicators Research, 93(2), 393-406. doi:10.1007/s11205-008-9331-7

Ware, J. E., \& Gandek, B. (1998). Methods for testing data quality, scaling assumptions, and reliability: The IQOLA Project approach. International Quality of Life Assessment. Journal of Clinical Epidemiology, 51(11), 945-952.

Ware, J. E., Snow, K. K., Kosinski, M., \& Gandek, B. (1993). SF-36 Health Survey manual and interpretation guide. Boston, MA: The Health Institute, New England Medical Center.

Westerhof, G. J., \& Keyes, C. L. M. (2010). Mental illness and mental health: The two continua model across the lifespan. Journal of Adult Development, 17(2), 110-119. doi:10.1007/ s10804-009-9082-y

Yamazaki, S., Fukuhara, S., \& Green, J. (2005). Usefulness of five-item and three-item Mental Health Inventories to screen for depressive symptoms in the general population of Japan. Health and Quality of Life Outcomes, 3(48), 1-7. doi:10.1186/1477-7525-3-48 


\section{Appendix}

\section{Mental Health Index (MHI-5)}

Instruções: Estas questões são sobre como você se sente e como tudo tem acontecido com você durante as últimas 4 semanas. Para cada questão, por favor, dê uma resposta que mais se aproxime da maneira como você se sente.

\begin{tabular}{ccccc}
\hline 1 & 2 & 3 & 4 & 5 \\
\hline Todo o tempo & $\begin{array}{c}\text { A maior parte } \\
\text { do tempo }\end{array}$ & $\begin{array}{c}\text { Alguma parte } \\
\text { do tempo }\end{array}$ & $\begin{array}{c}\text { Uma pequena parte } \\
\text { do tempo }\end{array}$ & Nunca \\
\hline
\end{tabular}

Em relação às últimas quatro semanas:

a. Quanto tempo você tem se sentido uma pessoa muito nervosa?

$\begin{array}{lllll}1 & 2 & 3 & 4 & 5\end{array}$

b. Quanto tempo você tem se sentido tão deprimido(a) que nada possa animá-lo(a)?

$\begin{array}{lllll}1 & 2 & 3 & 4 & 5\end{array}$

c. Quanto tempo você tem se sentido calmo(a) ou tranquilo(a)?

$\begin{array}{lllll}1 & 2 & 3 & 4 & 5\end{array}$

d. Quanto tempo você tem se sentido desanimado(a) e abatido(a)?

$\begin{array}{lllll}1 & 2 & 3 & 4 & 5\end{array}$

e. Quanto tempo você tem se sentido uma pessoa feliz?

$\begin{array}{lllll}1 & 2 & 3 & 4 & 5\end{array}$

